\title{
Characterization of Borrow Material for Embankment Fill and Capping Layer Based on Their Index and Strength: Case Study on Arbarakate to Gelemso road, W/Harerghe, Ethiopia
}

\author{
Shikuri Mahmud ${ }^{1, *}$, Nade Nuru ${ }^{2}$ \\ ${ }^{1}$ Agricultural \& Natural Resource Office, West Hararghe Zone, Chiro, Ethiopia \\ ${ }^{2}$ Institute of Technology, Oda Bultum University, Chiro, Ethiopia \\ Email address: \\ shikuribeker@gmail.com (S. Mahmud) \\ ${ }^{*}$ Corresponding author
}

To cite this article:

Shikuri Mahmud, Nade Nuru. Characterization of Borrow Material for Embankment Fill and Capping Layer Based on Their Index and Strength: Case Study on Arbarakate to Gelemso road, W/Harerghe, Ethiopia. American Journal of Traffic and Transportation Engineering. Vol. 5, No. 4, 2020, pp. 43-50. doi: 10.11648/j.ajtte.20200504.11

Received: August 14, 2020; Accepted: August 26, 2020; Published: September 14, 2020

\begin{abstract}
The Arba Rekete-Gelemso gravel Road section is affected by the presence of expansive soil, this soil has shrinking and swelling behavior due moisture fluctuation. The main objective of this research work is to investigate the Characterization of Borrow materials for embankment fill and capping layer based on their index and strength properties for Road Construction of the proposed route. In order to achieve the objectives, field investigation and nine (9) samples were also collected from the identified borrow area and laboratory test analysis were performed such as, Atterberg limits, compaction, CBR and percentage of swell tests. ERA's and AASHTO's standard technical specifications have been used to interpret the data by integrating the field with laboratory test results. The subgrade soil of route, having liquid limit value greater than $60 \%$ and plastic index value greater than $30 \%$ and CBR value less than $5 \%$, at Chainage km $0+000-4+000,5+900-8+000,9+400-$ $12+900, \quad 13+500-14+000, \quad 15+000-16+000, \quad 17+100-17+600, \quad 18+500-20+500, \quad 21+500-34+900, \quad$ and $\quad 35+200-47+000$ unsuitable. The index and strength properties of the borrow materials fulfill the requirement for embankment fill and subgrade improvements. Finally, all unsuitable subgrade soil along the study route corridor are recommended to remove and replace with suitable and non-expansive subgrade materials, since enormous amount of selected fill materials that fulfill the requirements for subgrade soils improvement are available nearby the study area.
\end{abstract}

Keywords: Borrow Materials, Embankment Fill and Capping Layer, Index and Strength Properties

\section{Introduction}

In Ethiopia, several rural road constructions have been carried out. Although, road construction activities increased from year to year, geological and geotechnical or engineering geological assessment was not given an attention for the road project, because of less emphasis given to the engineering geological investigation most of the constructed road prematurely failed. Good road construction are absolutely essential in order to provide goods and services to populations in remote villages, for administration purposes, for movement of agricultural products to larger cities, and for education and health programs of rural and urban peoples

Geological and Geotechnical investigation and characterization of sub grade soil is important component for the design and construction of road. In Arba Rekete -Gelemso road section, there is no detailed geological and geotechnical investigation that have been conducted before. The proposed road section has been upgrading to asphaltic road, so prior to the construction, the subgrade soil has to be properly investigated to ensure the suitability for road construction.

There are several methods that have been used to achieve the objective and among that, field investigation is one of the most essential, because the actual data were gathered from 
the field by conducting visual soil extension survey and dug the pit at minimum $0.5 \mathrm{~m}$ and maximum $1.2 \mathrm{~m}$ depth depending on the soil variation along the route corridor and sampling to conduct laboratory test to determine the index and strength properties of the subgrade soil and borrow materials. In the process of characterization, different techniques and procedures have been applied for interpretation of sub grade soil condition. These interpretation techniques are often specific to site and are influenced by geological, topographic, and climatic conditions. Hence, prior to road construction, the sub grade soils of the road have to be sampled and investigated to analysis its performance for road construction. All these engineering properties of the sub grade soils affect the riding quality and serviceability of the road with in the design life [3]. Therefore, to get reliable test results for evaluation of those engineering properties and minimize errors and deviation with regard to the inherent variability of the sub grade soils, proper sampling and testing are of paramount importance.

Expansive soils in construction sites have significant influence on planning, structural design, construction, maintenance costs, performance and engineering life, especially for shallow foundation structures like road. Expansive soils are susceptible to considerable volume changes with response to fluctuations in ground water table and moisture content following seasonal climatic variations. This property can cause severe damages to infrastructure unless proper measures are taken in the design and construction phases [4].
During investigation the geological and geotechnical problems associated with the road have been elaborated and appropriate mitigation measure have been suggested in this thesis.

In general, this research is aimed to characterize geological and geotechnical condition of subgrade soil on the basis at Arba Rekete-Gelemso road segment km $0+000$ to $60+000$.

\section{Methodology of the Study}

\subsection{Location of the Study Area}

The project is located in Oromia Regional State in West Hararghe Administrative Zone. The start of the project Arba Rekete junction ( $\mathrm{km}-0.0)$ is $326-\mathrm{km}$ far from Addis Ababa along Addis Ababa-Awash-Asebe Teferi-Dire Dawa main highway or 7-km from Asebe Teferi towards Dire Dawa side. It starts from the outskirt of Chiro (Asebe Tefri) town and stretches towards the southern direction. It traverses through important administrative and trade towns such as, Kuni, Bedesa, and Gelemso.

The geographic locations for the study area in particular is bounded approximately by the UTM coordinate 0709983E, $1001056 \mathrm{~N}$ at the starting point and $666451 \mathrm{E}, 974748 \mathrm{~N}$ at the ending point of the study area.

The study area from the starting of Arba Rekete Village $7 \mathrm{~km}$ and from the ending of Gelemso Town $67 \mathrm{~km}$, respectively far from the Zonal town Chiro and part of the study area, route having a total length of $60 \mathrm{~km}$.

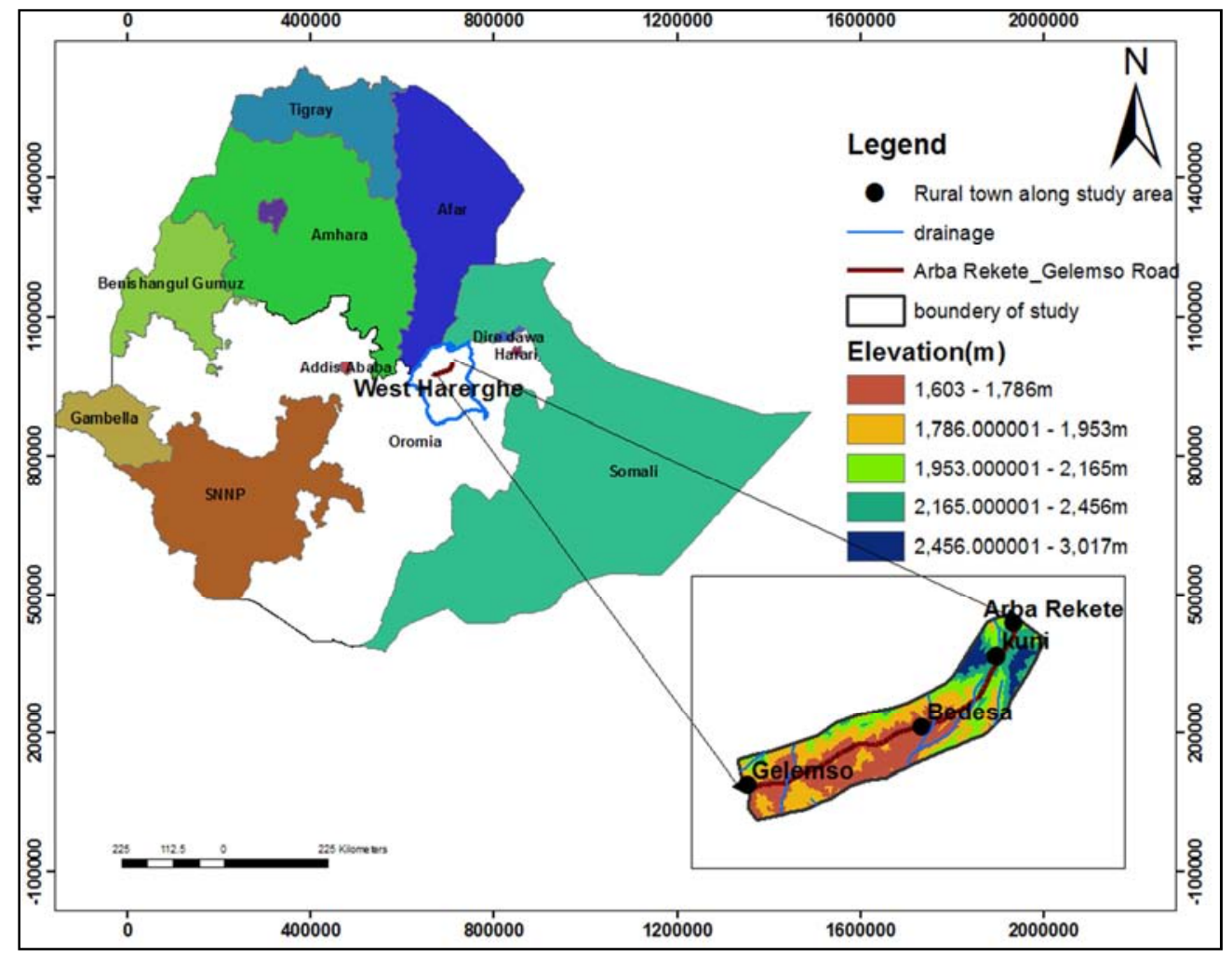

Figure 1. Location of the study area. 


\subsection{Data Collection Method}

The objectives of the present study have been achieved by using different systematic methodology. The following are main actions that are used to achieve the objectives of the study. Literature view: Prior to commencing the ground investigation, it has been reviewed of existing information through using published, unpublished reports and different standards, manuals and specifications have been used to understand or obtain more information regarding about the study topics. In addition, others relevant literatures such as about visual identification of subgrade soils, significance of subgrade soils, subgrade soil performance, about expansive soils, problems of expansive soils and possible mitigation measures were obtained to have good understanding about the study. Gathering and analysis of secondary data; the secondary data were obtained from governmental and non governmental agencies. For example the geological map of area at scale of $1 ; 250,000$, that used to acquire enough information about the local and regional geology of the route corridor was obtained from geological survey of Ethiopia, the topo map of West Hararghe zone at scale 1:50,000 and deep water well data that used to understand the ground water condition of the route were obtained from west Hararghe Zone Water Mineral and Energy office and DEM and satellite image (land sat 2000), that also important to know or identified drainage, slope and the structure of the research area, were also obtained from private person. In the field, before directly conducting subsurface investigation a visual sub grade soil extension survey has been carried out to determine the type and extent of the sub grade materials that made up the roadbed and the availability of potential borrow source for subgrade improvement and embankment fills. These extensions were then used during the test pitting and sampling to avoid narrow soil stretches from being overlooked. Sub grade soils with nearly similar soil type are grouped together and their extent was determined. These extensions were then used during the test pitting and sampling to avoid narrow soil stretches from being overlooked. It is necessary to group the subgrade soils of a road alignment in to uniform sections differentiating them based on their strength property or their CBR values after the obtained the laboratory test results. For the identification of the homogenous sections the first method to be used is visual surveying of the different soil extensions of the subgrade. Investigation of the lateral variation of the geological units and soil types of the selected borrow material sources for subgrade replacement, embankment and capping layer has to be also integrated in the field visual investigation. The field works have been supported by geological map of Bedesa area and topographical map, to get various inputs for the description on the topography and local geology situation. The soil extension types along the route and the embankment fill materials have been identified visually. Field identification and description of sub grade soils were based on color, texture as well as on the assessment of their consistency and proportion of fine and coarse fractions. Test Pitting and Sampling have been used to examine the subsurface engineering behavior of the subgrade soils test pits have been dug at $500 \mathrm{~m}$ average interval with minimum $0.5 \mathrm{~m}$ and maximum $1 \mathrm{~m}$ depth based on the existing soil variation along the study alignments. Laboratory investigation works involves the samples from each of the test pit, have been taken at an average interval of $0.5-\mathrm{km}$ for conducting soil tests such as; Atterberg limits and grain size analysis, modified proctor density (MDD), Optimum Moisture Content (OMC), California Bearing Ratio (3 point CBR), tests have been carried out according to [1] testing methods. Data analysis and Interpretation were done by integrating the results obtained from geotechnical field investigations and laboratory test results. This has been done by comparing the index and strength properties of the soils with the standard recommendations suggested by [8] and [1]. The materials that have been used during data processing, analysis and interpretation and preparing maps are:-Arc GIS 10.0, Global Mapper 11, Microsoft Office (word and excel) software.

Table 1. AASHTO and ASTM standards employed for the visual identification and laboratory testing of soil samples.

\begin{tabular}{llll}
\hline S. No & Test type & Test Designation & To characterized \\
\hline 1 & $\begin{array}{l}\text { Practice for Description and Identification of Soils (Visual- } \\
\text { Manual Procedure) }\end{array}$ & ASTM D2487 & $\begin{array}{l}\text { Subgrade soil } \\
\text { Borrow materials/Embankment fill and capping layer/ } \\
\text { Subgrade soil }\end{array}$ \\
2 & $\begin{array}{l}\text { Sieve Analysis (Gradation) for Particle-Size Analysis of Soils } \\
\text { Borrow materials/Embankment fill and capping layer/ }\end{array}$ & AASHTO T27 & $\begin{array}{l}\text { Subgrade soil } \\
\text { Borrow materials/Embankment fill and capping layer/ }\end{array}$ \\
3 & $\begin{array}{l}\text { Atterberg limits determination for Liquid Limit, Plastic Limit, } \\
\text { and Plasticity Index of Soils }\end{array}$ & AASHTOT89\&90 & Subgrade soil \\
4 & $\begin{array}{l}\text { Laboratory Compaction using Modified proctor compaction } \\
\text { Borrow materials/Embankment fill and capping layer/ }\end{array}$ & AASHTO T-180 & Subgrade soil \\
5 & $\begin{array}{l}\text { Soil classification using Atterberg limits and particle size } \\
\text { analysis }\end{array}$ & AASHTO M-145 & Borrow materials/Embankment fill and capping layer/ \\
& California Bearing Ratio (CBR) & AASHTO T-193 & $\begin{array}{l}\text { Subrade soil } \\
\text { Borrow materials/Embankment fill and capping layer/ }\end{array}$ \\
\hline
\end{tabular}




\section{Results and Discussion}

\subsection{General}

Borrow materials are vital for embankment, capping layer and improve the subgrade soil and resist the load that imposed on the subgrade. The materials have been obtained from adjacent roadway for the majority of the stretch. The weathered to decomposed rock material which are suitable for embankment fill and capping layer have been used as borrow sources where the natural sub grade material soil is poor to improve the strength of the subgrade soil.

\subsection{Borrow Site Investigation}

During detailed engineering investigations, construction materials sources which are available within the study area were identified and investigated. During the field investigations, nine (9) potential borrow sources were examined in terms of material types, overburden thicknesses; accessibility and the available quantity of the useful material were estimated. Finally their positions were recorded with the use of hand held GPS. In order to determine the properties of the borrow soil, samples are often obtained from the potential borrow area for laboratory analysis in accordance with [1] test methods. The summery of the laboratory test results for the construction materials borrow pits. The study route corridor soils with their strength meet the requirement of embankments fill and for improved subgrade soil, which have been tested and collected during the sub-grade sampling, can be also considered to represent the materials over the adjacent areas.

Hence the use of borrow materials from road sides can be inferred from that of the test result of the adjacent subgrade test pits for general fill and improved subgrade material.

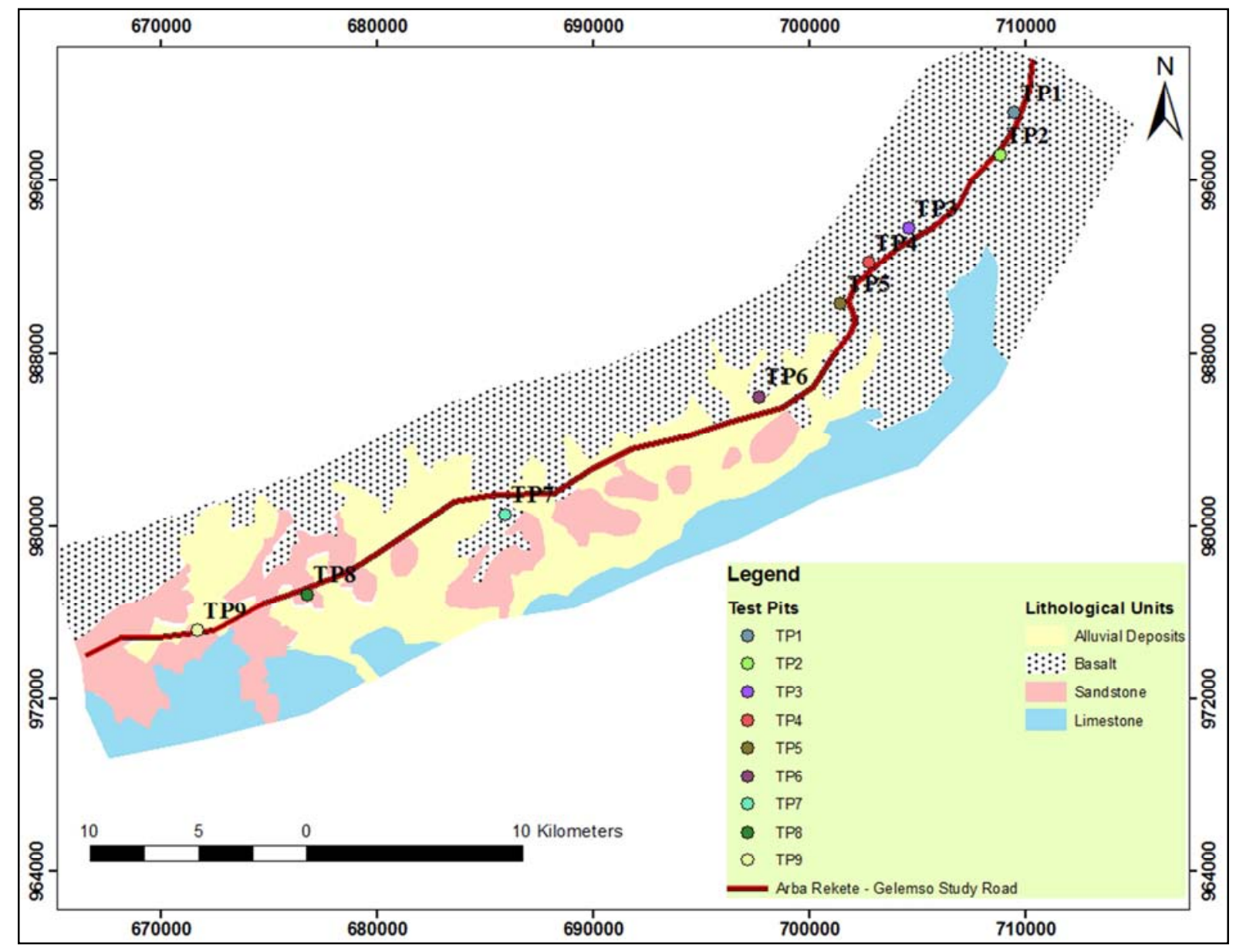

Figure 2. Location map of borrow materials overlaid on geological map of the route corridor.

\subsection{Laboratory Test Result Interpretations}

Samples from borrow material sources were collected and brought to Laboratory testing. Both [2] and Unified Soil Classification system are used for soil classification purpose. In the present study, the material tests that are normally performed on borrow soil are the grain size analysis,
Atterberg limits, Compaction (moisture- density relationship), CBR and Swell, in order to characterize the suitability of the borrow materials for capping layer and embankment fill.

Borrow materials can be characterized by using [7]. According to [8] the borrow materials for improved subgrade soil should allowed the maximum value of liquid limit $60 \%$, 
the plasticity index $30 \%$, the four day soaked CBR value $15 \%$ and CBR swell $2 \%$.

\subsubsection{Particle Size Distribution}

For the particular research area nine borrow materials sample have been subjected to laboratory test to determine the distribution of particle size, which predominantly exposed along the route. The particle size has a great effect in any engineering construction like road, since the fine grain materials dictate engineering performance of the road. To improve the poor subgrade soil of the study route, selecting of good embankment fill or capping layer are the prime concern for road construction.

In the present study, the result of grain size analysis show that the fine particle of borrow materials fall in range of $7 \%$ $-24.50 \%$. Based on [2] classification all of the borrow samples of the study area have fine particles less than $35 \%$, So they are grouped under granular materials and they are suitable to use as an embankment fill or subgrade soil improvements.

\subsubsection{Atterberg Limits}

Embankment fill or capping layer can be characterized using liquid limit and plastic index parameters.
On the other hand, Liquid limits and the plasticity index are used in the identification and classification of soils. Generally, borrow materials having high values of liquid limit and plasticity index are poor as embankment fill and subgrade improvements materials. Both the liquid limit and plastic limit depend on the type and amount of fine particles. The range of liquid limit and plastic index of borrow materials in the study area have $26-58 \%$ and $14-19 \%$ respectively.

According to [11], the liquid limit value greater than $35 \%$ and plasticity index greater than $15 \%$ is not suitable to use as embankment fill or capping layer. As comparing the study area laboratory result data such as plasticity index and liquid limit value with [11], only one borrow sample of liquid limit and two borrow sample of plasticity index are satisfied the requirement, the rest are beyond the specified limit. But based on the Ethiopian Roads Authority standard specification [7], the research road corridor of all borrows materials of liquid limit and plasticity index comply the requirements. Therefore, the borrow materials of study area are good to use as subgrade improvements and embankment fill.

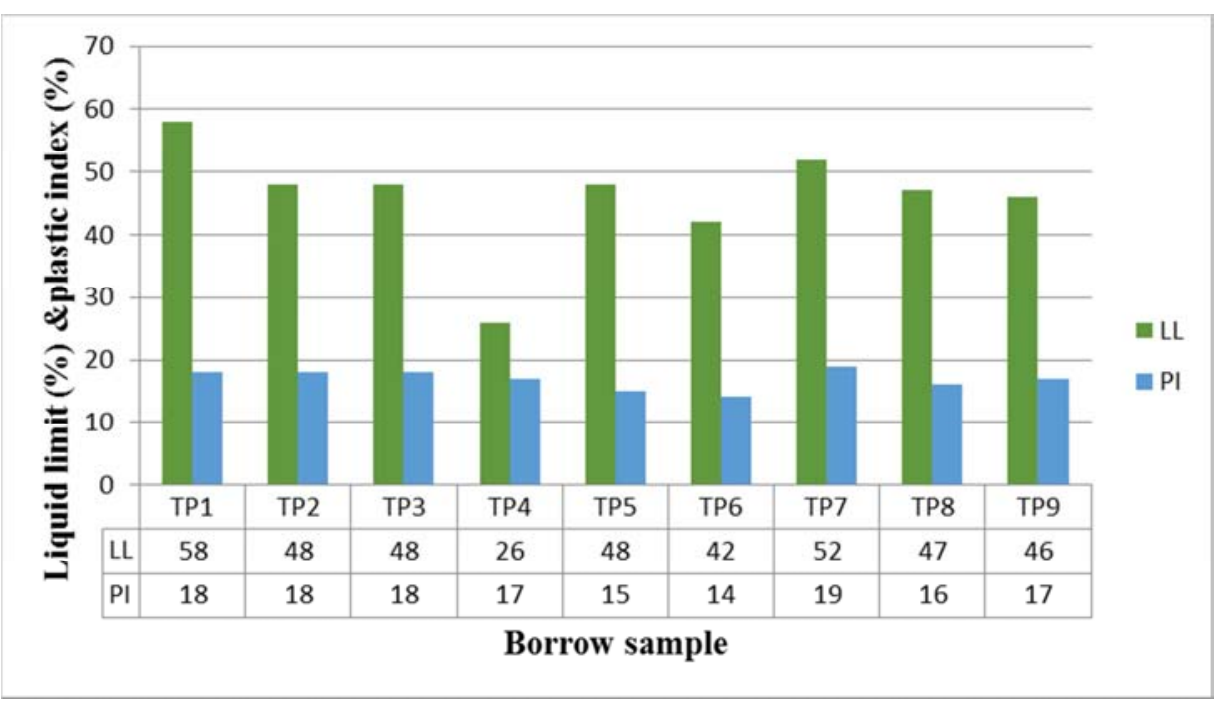

Figure 3. Liquid limit and plasticity index value for the borrow samples.

\subsubsection{Soil Classification}

Classification of borrow materials using AASHTO's system is pertinent to characterized the embankment fill or capping layer for the study route corridor. The grain size test result in combination with liquid limits and plasticity index laboratory test results have been employed for the soil classification purpose. From the data obtained from grain size analysis tests, liquid limit and plasticity index, the borrow materials of the study route has been categorized under granular materials, using well known soil classification system the called AASHTO method. Based on AASHTO method of the present study, eight borrow materials sample classified under A-2-7 and only one sample classified under A-2-6 soil classes.

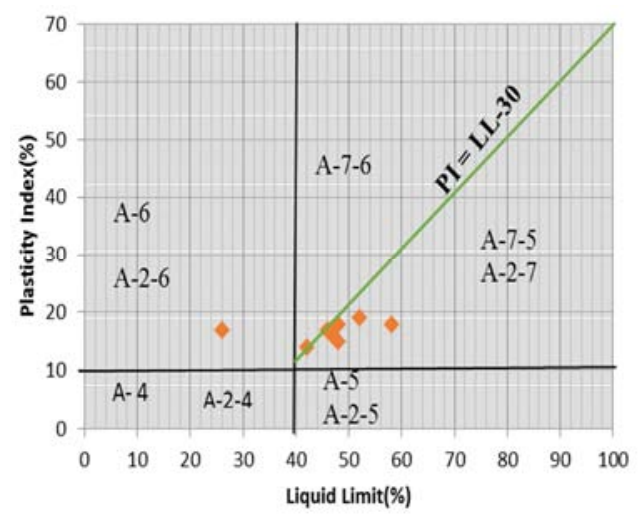

Figure 4. Plot of LL-PI of the Borrow materials as per AASHTO Plasticity chart. 
Therefore, it can be deduce that, almost all sample of borrow materials are granular materials and good to use for embankment fill, capping layers and subgrade soil improvements.

The borrow materials classification for embankment fills are shown below on AASHTO plasticity chart at figure 4.

\subsubsection{Compaction (Density-moisture Relationship)}

According to Das, (2007) increasing compaction effort, the modified proctor test result in an increase in maximum dry density of the soil. The increase in the maximum dry unit weight is accompanied by a decrease in the optimum moisture content.

For the proposed nine sample of borrow materials of the study area, laboratory modified proctor compaction
AASHTO T 180 has been subjected to determine the maximum dry density and optimum moisture content. This compaction test was conducted for the sack of four day soaked California bearing ration (CBR) evaluation. The engineering uses of soils are involved with placement and compaction of soil materials in road construction.

The optimum moisture content and maximum dry density of the borrow materials ranged $12.5 \%$ to $23 \%$ and $1.53 \mathrm{~g} / \mathrm{cc}$ to $1.93 \mathrm{~g} / \mathrm{cc}$ respectively. As shown at figures below indicate that, the higher dry density obtained at lower optimum moisture content. On another hand the strength of the proposed materials prominently good, so it is better to use as embankment fill and subgrade soil improvements.

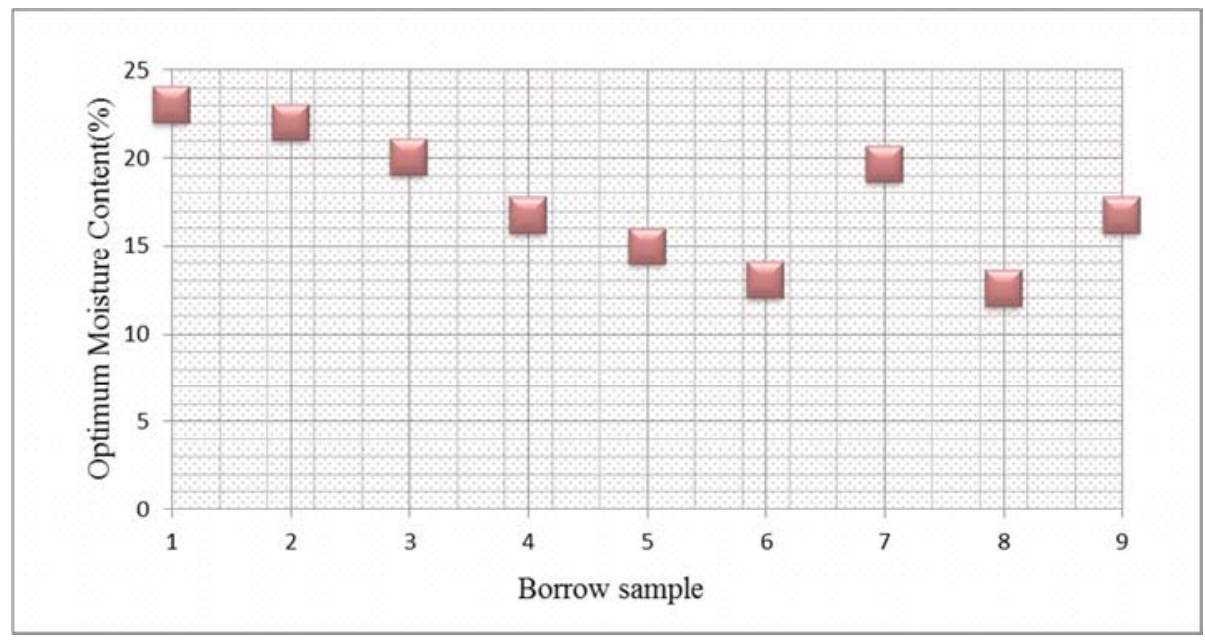

Figure 5. Optimum moisture contents versus borrow sites.

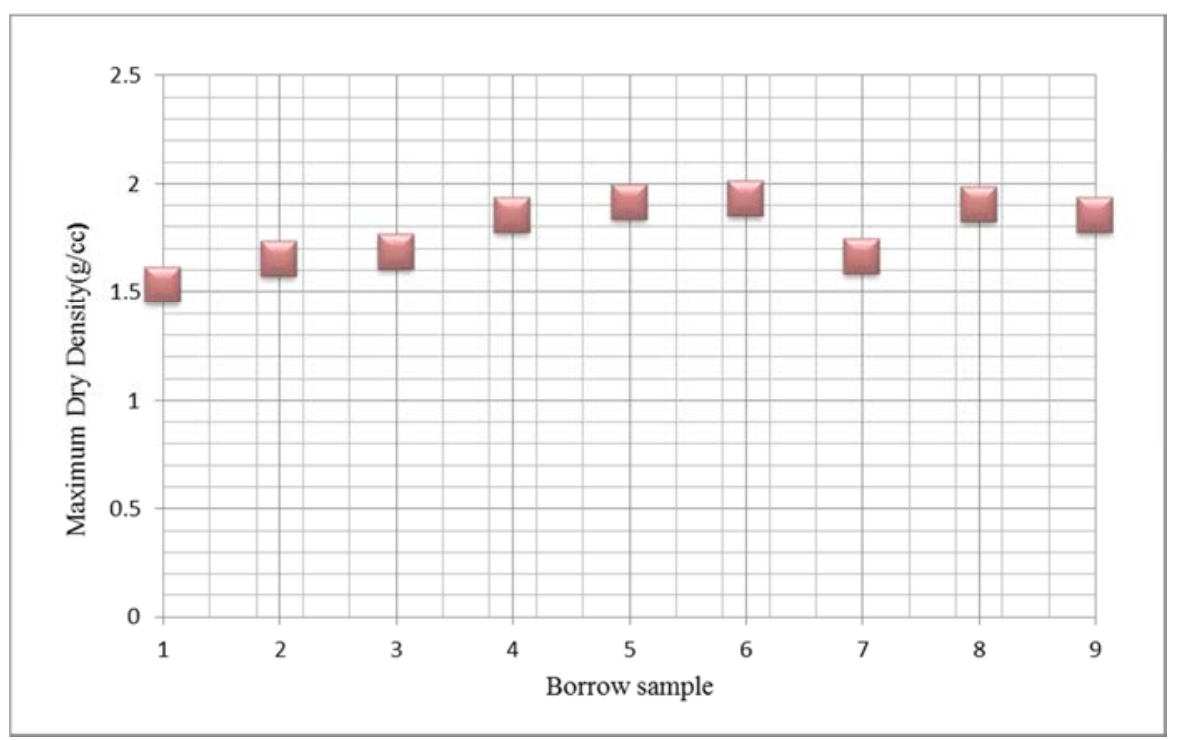

Figure 6. Maximum dry densities versus borrow sample.

\subsubsection{California Bearing Ratio (CBR) and Percentage of CBR Swell}

The strength of borrow materials is paramount important for suitability and performance of embankment fill in any engineering structures. To characterize or determine the strength and swelling potential of a borrow materials for embankment fill and subgrade improvement, 9 sample have been conducted to laboratory test. The test was used modified compaction using [1] test method. According to [6] the CBR value of capping layer is greater than $15 \%$. The CBR value of borrow materials ranges $23 \%$ to $63 \%$. This CBR test results implies that all samples fulfill the requirements. As roads are 
built relying on the soils along the road line, it is useful to assess the performance and features of local soils. The properties of the soils have an important bearing on how the road surface performs when subjected to traffic and weather. The fine materials are not good to use as road construction due to poor performance when they are wet. The borrow materials of the study road alignment has granular materials, because the all soil sample are below $35 \%$ of [2] soil classification. Therefore, all borrow samples are good for the use of embankment and capping layers.

The percentage swell of borrow materials ranges from $0.2 \%$ to $0.5 \%$. According to [6], the maximum permissible value of CBR swell is $2 \%$. All the borrow materials satisfy the requirements. Hence, the borrow materials of a given study area are granular materials so it is good to use for embankment fills or capping layer and subgrade improvements.

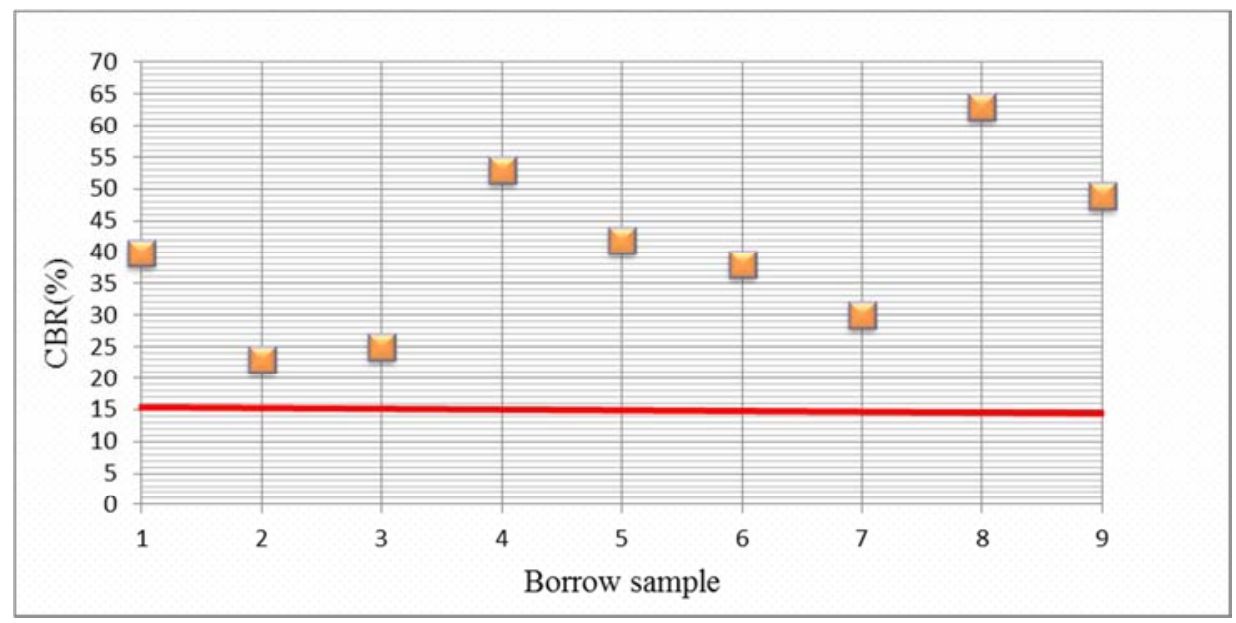

Figure 7. CBR value of borrow materials.

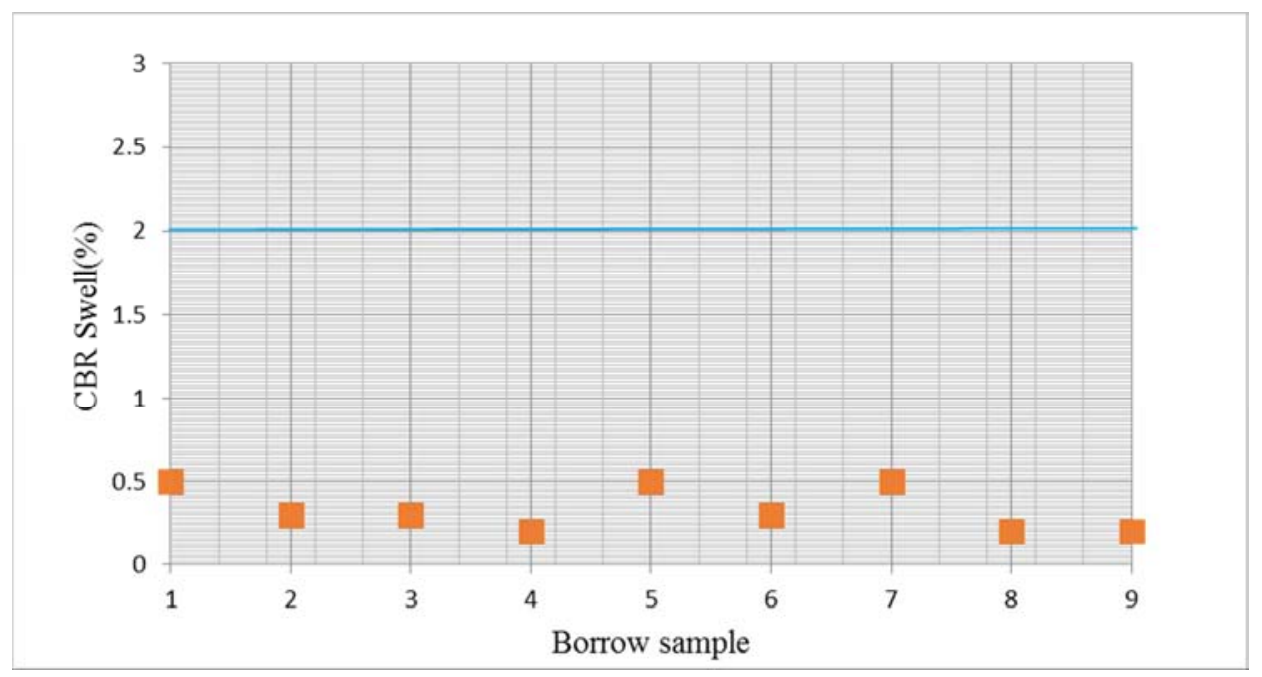

Figure 8. Percentage value of CBR swell of the borrow materials.

\section{Conclusion}

The Geological units which are found along project road segment are the alluvial sediments, volcanic rocks such as basalt and sedimentary rocks such as limestone and sandstone. The Arba Rekete Gelemso Road Section has a serious of slope instability especially at the mountainous terrain, since this road section has poor drainage system. To characterize a borrow materials using grain size analysis, Atterberg limits, MDD, OMC and CBR and CBR swell testes, 9 borrow material samples were subjected to laboratory tests. All borrow materials laboratory test result show that, the liquid limit, the plastic index, CBR and CBR swells fulfill the requirement that sets by Ethiopia Road
Authority standard technical specification 2002, so they are good to use for embankment fill and capping layer and subgrade improvements. The nine borrow materials sample are grouped under A-2-7 and A-2-6 soil class as per [2] soil classification system.

\section{References}

[1] American Association of State Highway and Transportation Officials (1993). "AASHTO Guide for Design of Pavement Structures," Washington, D. C U.S.A.

[2] American Association of State Highway and Transportation Officials (2000). "AASHTO Guide for Design of Pavement Structures," Washington, D. C U.S.A. 
[3] Atkins, H. N. (2003), Highway Materials, Soils and Concretes, 4th Edition, Prentice Hall, Upper Saddle River, New Jersey.

[4] Chen, F. H. (1988). Foundations on Expansive Soils, pp. 1-40. New York, USA: Elsevier Science Publishing Company Inc.

[5] Das, B. M, (2006 \& 2007. Principles of Geotechnical engineering fifth\& seven edition California State University, Sacramento.

[6] Ethiopian Roads Authority (2002). Site Investigation Manual. Addis Ababa, Ethiopia: ERA.

[7] Ethiopian Roads Authority (2002). Geometric Design Manual. Addis Ababa, Ethiopia: ERA.

[8] Ethiopian Roads Authority (2002). Pavement Design Manual, Flexible Pavements and Gravel Roads, (I). Addis Ababa, Ethiopia: ERA.

[9] Ethiopian Roads Authority (2002). Standard Technical Specification Manual. Addis Ababa, Ethiopia: ERA.

[10] Ethio-Infra Engineering PLC (2012). Soils and Materials
Report of Arba Rekete-Gelemso Road Project. Addis Ababa, Ethiopia. Unpublished.

[11] IS-1498. (1997). "Indian standard methods of test for soils," first revised, bureau of Indian standards manak bhavan, 9 bahadur shah zafarmarg, New Delhi, Indian.

[12] Seifemichael, B. (1985), The Geological Map of Dire Dawa (Map Sheet NC 37-12), EIGS, printed by Ethiopian Mapping Agency, Addis Ababa.

[13] Subah. T \& Tapas. K (2011), A Study on Variation of Test Conditions on CBR Determination, BSc Thesis in Civil Engineering, National Institute of Technology, Rourkela.

[14] Tesfaye, K.; Acocella, V.; Bekele, A. (2004). The Role of Preexisting Structures in the Origin, Propagation and Architecture of Faults in the Main Ethiopian Rift. Gondwana Research, Vol. 7, No. 2, pp 467-479.

Zerihun. M (2016) Geological and geotechnical characterization of Bahr Dar-Kunzala Gravel Road Project with special emphasis on subgrade soil, North West Ethiopia, Unpublished, M.Sc thesis in School of Earth Science, Mekelle University. 